\title{
DISCRICIONARIEDADE EM POLÍTICA URBANA: O CASO DO VIADUTO ESTAIADO DE CURITIBA
}

\section{ADMINISTRATIVE DISCRETION IN URBAN POLICY: THE CASE OF THE VIADUTO ESTAIADO IN THE CITY OF CURITIBA (PR)}

Edimur Ferreira de Faria ${ }^{1}$ Ana Maria Isar dos Santos Gomes²

Resumo: O objetivo do artigo é analisar o controle judicial de atos administrativos que traduzem decisões de política urbana. Por meio de pesquisa bibliográfica e documental, investiga-se o caso do Viaduto Estaiado (Curitiba), construído no âmbito das medidas preparatórias para os jogos da Copa do mundo de 2014. Conclui-se que atos destinados à melhoria da estrutura viária estão vinculados à existência de previsão no plano diretor e de mobilidade urbana do município, de caráter obrigatoriamente participativo. No caso em estudo, a urgência das medidas preparatórias para a Copa dispensa tal previsão, mas não a inclusão da obra na matriz de responsabilidade.

Palavras-chave: Discricionariedade Administrativa. Política Urbana. Viaduto Estaiado. Planejamento Urbano. Participação.

Abstract: The objective of this article is to analyze the judicial control of administrative acts that reflect urban policy decisions. By means of bibliographical and documentary research, it investigates the case of Viaduto Estaiado, in Curitiba (PR), constructed to prepare the city to 2014 World Cup. The article concludes that administrative acts intended to improve the road structure have to be forecasted in municipality's urban master plan and urban mobility plan, which are mandatorily participative. The urgency of the preparatory measures for the World Cup exempts it, but obliges the inclusion of the construction in the matrix of responsibilities.

\footnotetext{
${ }^{1}$ Doutor e mestre pela Universidade Federal de Minas Gerais, professor da graduação e do Programa de Pósgraduação em Direito (mestrado e doutorado) da Pontifícia Universidade Católica de Minas Gerais, excoordenador do Curso de Direito, ex- Diretor da Faculdade Mineira de Direito, PUC Minas, ex-Diretor da Escola de Contas e Capacitação do Tribunal de Contas de Minas Gerais, ex-Presidente do Instituto Mineiro de Direito Administrativo. Pontifícia Universidade Católica de Minas PUC Minas. Brasil. E-mail: edimurfaria@hotmail.com 2 Doutoranda em Direito na Pontifícia Universidade Católica de Minas Gerais PUC Minas. Mestre em Geografia (Gestão Ambiental e Territorial) pela Universidade de Brasília UnB (2013), com dissertação sobre democracia participativa na regularização fundiária urbana. Especialista em Direito Público pelo Instituto Brasiliense de Direito Público IDP (2008). Procuradora do Distrito Federal com atuação nas áreas de Direito Urbanístico, Ambiental e Imobiliário. Membro de Grupo de Pesquisa do Núcleo de Estudos Urbanos e Regionais da UnB vinculado ao CNPQ. Principais áreas de atuação: Direito Constitucional, Direito Urbanístico, Direito Ambiental e Direito Econômico. Pontifícia Universidade Católica de Minas PUC Minas. Brasil. E-mail: anaisar@uol.com.br
} 
Key-Words: Administrative Discretion. Urban Policy. Viaduto Estaiado. Urban Planning. Participation.

Introdução

Os administrativistas pátrios ainda divergem quando se trata de discricionariedade administrativa. O amplo leque de posições doutrinárias compreende desde os que rejeitam o controle judicial dos atos discricionários (exceto quanto à sua forma), como Celso Antonio Bandeira de Mello (2012), até aqueles que, como Georges Abboud (2014), defendem a completa supressão da discricionariedade administrativa. A preocupação com o tema levou o jurista alemão Hans Huber a chamar a discricionariedade de "cavalo de tróia" do Direito Administrativo, o que parece justificarse, na medida em que a competência conferida ao administrador público para eleger critérios de conveniência ou oportunidade pode ensejar a prática de atos arbitrários.

Por outro lado, como não é possível ao legislador prever todas as situações com as quais a Administração se defronta diariamente, ele se vê obrigado a deixar à critério desta última, em determinadas situações, a melhor forma de aplicar a norma legal no caso concreto. Em caso de dúvida, cabe ao Poder Judiciário, se provocado, aferir se o ato praticado pelo agente competente está em conformidade com a lei e a Constituição. Contudo, existem atos administrativos que não dependem de mera decisão acerca da melhor forma de aplicar a norma, mas envolvem escolhas políticas. Na medida em que tais atos materializam decisões da comunidade - veiculadas de forma indireta, por seus representantes políticos, ou direta, por meio dos mecanismos e canais de participação (artigo 1o, parágrafo único, da Constituição Federal de 1988) - seu conteúdo não deve, ou não deveria, ser revisto pelo Poder Judiciário.

Delineia-se, assim, conflito entre o princípio da separação dos poderes, de um lado, e a necessidade de controlar os atos praticados pela Administração para evitar que se tornem arbitrários, de outro. O artigo se ocupa desse problema, que pode ser traduzido em duas questões, assim encadeadas: o Poder Judiciário pode exercer controle sobre o mérito de ato administrativo que reflete uma escolha de política pública, mais especificamente da política urbana ? Se afirmativo, que critérios podem ser utilizados para aferir se o conteúdo do ato administrativo é ou não válido, ou, em outras palavras, como julgar se o administrador escolheu a melhor alternativa?

Traz-se à tona um exemplo tomado do livro Discricionariedade Administrativa $e$ Hermenêutica, de Luis Henrique Madalena, a saber, a construção do Viaduto Estaiado de Curitiba, no âmbito dos preparativos para a Copa do Mundo de 2014. O custo elevado da obra - cerca de vinte vezes maior do que o de um viaduto comum - é justificado, segundo a Prefeitura, pela necessidade de estimular o turismo na cidade e manter um vão livre abaixo do viaduto para a passagem de um 
sistema de transporte coletivo a ser implementando futuramente. O caso em análise permite construir as seguintes hipóteses de pesquisa: o ato administrativo que autorizou a construção de uma obra de arte especial a um custo vinte vezes maior do que o usual, com a finalidade de atender a escolhas previamente adotadas no âmbito de políticas públicas, é vinculado ou discricionário? Tal ato pode ter seu mérito submetido a controle judicial e, em caso positivo, qual seria o critério para aferir se ele representa a melhor escolha da Administração?

A pesquisa bibliográfica se vale das reflexões de Lênio Streck para reconstruir, na primeira seção, o desenvolvimento histórico do conceito de discricionariedade administrativa. Apresenta, ainda, a contribuição de Edimur Ferreira de Faria, Georges Abboud e Luis Henrique Madalena, autores que admitem o controle do mérito do ato administrativo discricionário em menor ou maior grau. A segunda seção consiste na investigação, por pesquisa documental e bibliográfica, do estudo de caso. Com base em estudo de Maria das Graças Rua, a análise utiliza conceitos da ciência política para investigar se a decisão de construir o Viaduto Estaiado foi uma decisão executivo-administrativa ou a materialização de uma escolha política anterior. Na terceira seção, discute-se qual é a margem de discricionariedade concedida ao administrador para a tomada de decisões de política urbana, bem como a possibilidade de controle jurisdicional do mérito dos atos discricionários vinculados a decisões políticas previamente adotadas. A pesquisa conclui que obras de melhoria do sistema viário que importem em intervenção no espaço urbano, como a construção do Viaduto Estaiado, devem estar obrigatoriamente previstas nos planos municipais de ordenação do território (plano diretor e plano de mobilidade urbana) e no Plano Plurianual do Município - de caráter participativo - o que reduz a zero a discricionariedade do administrador público. No caso do Viaduto Estaiado, a urgência determinada pela necessidade de realização de obras preparatórias para a Copa do Mundo dispensa a previsão nos planos de ordenamento territorial, mas impõe a inclusão da obra na matriz de responsabilidades, o que não ocorreu. $\mathrm{O}$ ato administrativo que determinou a construção do viaduto parece, assim, inválido. É o que se pretende provar no curso deste artigo.

\section{Discricionariedade Administrativa no Pós-Positivismo: a escolha da única resposta correta}

As divergências doutrinárias em relação ao tema da discricionariedade administrativa começam pela própria existência de atos administrativos decorrente do poder discricionário. Abboud (2014), por exemplo, sustenta que, "o avanço do processo civilizador [...] reduziu a dimensão da discricionariedade no direito administrativo, a ponto de podermos defender sua completa supressão atualmente" (ABBOUD, 2014, p. 483). Para compreender melhor essas divergências, 
convém trazer algumas questões conceituais. Tradicionalmente, a discricionariedade é vista como margem de livre apreciação conferida ao administrador para escolher a melhor solução administrativa de acordo com critérios de conveniência ou oportunidade. Tal margem de liberdade só existe quando o administrador se defronta com uma norma legal de textura aberta (caso contrário o ato administrativo é vinculado ao texto legal). As normas de textura aberta, por sua vez, decorrem não só da impossibilidade de se prever regras gerais para todas as situações do dia a dia, mas também da própria indeterminação dos conceitos.

No primeiro caso, pode ocorrer que uma norma legal deixe em aberto os pressupostos de fato para a prática de ato administrativo; ou não especifique se determinado ato deva ou não ser praticado, em determinada situação; ou, ainda, apresente ao administrador várias opções de conduta a serem adotadas diante de um mesmo pressuposto fático. Em todos esses casos, a solução deve ser encontrada, segundo a doutrina tradicional, mediante a técnica da ponderação ou valoração de interesses: o administrador deverá sopesar quais são os interesses envolvidos na situação e encontrar, dentre as várias soluções possíveis, aquela que melhor concretiza o interesse público, revelado pela finalidade da norma legal. Tal tarefa é orientada, conforme ensinam os administrativistas, pelos critérios extrajurídicos de conveniência e oportunidade, pelos princípios constitucionais da Administração Pública e pelos princípios gerais do Direito, como a razoabilidade e a proporcionalidade.

O segundo caso de discricionariedade acontece quando a norma contém conceito indeterminado, isto é, um conceito que não delimita de forma inequívoca e precisa o fato concreto ao qual se refere, de forma que seu sentido precisa ser complementado por elementos extralegais. Nesses casos, a complementação se dá, também, pela técnica de ponderação de interesses, segundo critérios de conveniência e oportunidade. Moraes (2004) chama a atenção para o fato de que, em muitos casos, embora o conceito seja indeterminado, sua determinação no caso concreto não depende de atividade discricionária. Isso acontece quando não há necessidade de se realizar uma valoração ponderativa de interesses, mas apenas um esforço de interpretação da linguagem ou uma avaliação "das circunstâncias de fato presente e concomitantes à incidência da norma" (MORAES, 2004, p. 202).

Para compreender como se desenvolve a teoria da discricionariedade administrativa, é interessante lembrar que o Estado Moderno surge calcado no ideal do individualismo liberal e tem seu fundamento jurídico-filosófico em uma ficção criada por Thomas Hobbes, na obra Leviatã: a vontade do povo. Representada pelo Parlamento e traduzida nas leis, a vontade do povo substitui a vontade do rei. Surge, assim, o princípio da legalidade administrativa, segundo o qual o 
administrador se subordina ao poder normativo expresso na lei (MADALENA, 2016). Como a vontade - que antes era do monarca - se desprende do seu emissor (o povo) no momento em que se transforma em lei, ela precisa, agora, ser interpretada. Na primeira fase do positivismo, denominada de exegética ou legalista, a técnica utilizada para interpretação da lei - consentânea com a ideia iluminista de predomínio da razão humana - é a análise sintática das proposições normativas. O sentido da norma é extraído, assim, da conexão lógica entre os signos (STRECK, 2014).

Contudo, afirma Streck (2014), a ideia de legalidade estrita, tão útil ao Estado Moderno, é colocada em xeque com o advento do Estado de Bem-Estar Social. Já não é mais suficiente proteger o cidadão contra o poder dos governantes para que ele desenvolva ao máximo suas potencialidades individuais (ideal do liberalismo). É necessário, também, garantir direitos sociais, cuja efetivação depende de uma atuação mais comissiva por parte da Administração Pública. Para Streck (2014), a passagem do Estado Moderno para o Estado de Bem-Estar Social e o consequente fortalecimento do poder regulatório do Estado, a partir das décadas de 1930 e 1940, marca a "falência dos modelos sintático-semânticos de interpretação da codificação" e o surgimento, em primeiro plano, do "problema da indeterminação do sentido do Direito" (STRECK, 2014, n.p.).

Para responder ao enfraquecimento dos modelos sintático-semânticos - ameaçados pela jurisprudência dos interesses e pela Escola do Direito Livre, que pregam a introdução de elementos extrajurídicos (psicológicos, políticos e ideológicos) na atividade interpretativa - surge o positivismo normativo (STRECK, 2014). Com o intuito de dar cientificidade ao Direito, Hans Kelsen separa o sistema de normas jurídicas (dever ser) da realidade fática (ser): o conteúdo do direito passa a ser construído por meio de mero procedimento de adequação do caso concreto à moldura da norma jurídica. Contudo, como o próprio Kelsen reconhece, existem várias interpretações possíveis dentro de uma mesma moldura jurídica dos fatos, e, portanto, mais de uma solução jurídica consentânea com a norma.

O problema de interpretação da norma é deslocado, assim, da sintaxe (conexão lógica entre os signos) para a semântica (escolha de um entre vários sentidos da norma), como percebe Streck (2014). No famoso capítulo VIII da Teoria Pura do Direito, no qual formula a ideia da moldura jurídica, Kelsen admite que a interpretação é, ao fim e ao cabo, uma atividade discricionária:

A interpretação jurídico-científica tem de evitar, com o máximo cuidado, a ficção de que uma norma jurídica apenas permite, sempre e em todos os casos, uma só interpretação: a intepretação "correta". Isto é uma fiç̧ão de que se serve a jurisprudência tradicional para consolidar o ideal da segurança jurídica. Em vista da plurissignificação da maioria das normas jurídicas, este ideal somente é realizável aproximativamente. (KELSEN, 1987, p. 371) 
O dilema do positivismo normativo, segundo Madalena (2016), é que ao mesmo tempo em que abre a possibilidade de escolha do intérprete dentre vários sentidos atribuídos à norma jurídica, vale-se do interesse público para nortear essa escolha ${ }^{1}$. Surge, portanto, a questão de se identificar qual seria o interesse público a refletir o "bem da sociedade". Como a legitimidade para definir qual é o interesse público é atribuída com exclusividade ao administrador, uma vez que os atos resultantes do poder discricionário não têm seu mérito revisto pelo Poder Judiciário, abre-se caminho para a arbitrariedade (MADALENA, 2016) ${ }^{2}$.

O modelo positivista normativo é contestado, em meados do século passado, por Eduardo García de Enterría. Enterría (1962) defende o controle jurisdicional de toda atividade administrativa, inclusive quanto ao mérito, sob o pressuposto de que a lei não confere ao administrador competência discricionária para escolher entre várias soluções possíveis. Ao contrário, existe apenas uma solução possível, a ser encontrada por meio da melhor interpretação da lei. No Brasil, Faria (2016), um dos primeiros autores a sustentar a possibilidade de revisão do mérito do ato administrativo discricionário, afirma a existência de apenas uma escolha correta na aplicação da lei ao caso concreto: aquela que alcança a finalidade da norma legal (mens legis). Dessa forma:

[...] o Judiciário, no desempenho de suas funções constitucionais, está legitimado a sindicar o mérito do ato administrativo, com o objetivo de verificar se o agente realizou a escolha correta. Constatada a impropriedade da opção adotada, impõe-se o dever de declarar a nulidade do ato. Nesse caso, caberá à autoridade adotar outra escolha que melhor atenda à vontade da lei na situação fática, se a hipótese existir. (FARIA, 2016, p. 293)

Como se percebe, a discricionariedade encontra-se em uma balança, onde pende, de um lado, a interpretação do administrador acerca do que seria a vontade da lei no caso concreto, norteada pelo interesse público, e, de outro, a interpretação do juiz. O risco a ser enfrentando, quando se transfere o controle do mérito do ato discricionário para o Poder Judiciário, é dar azo ao decisionismo jurídico. Ou seja: transfere-se a competência para escolher a solução correta do Poder Executivo, que detém representatividade popular, para o juiz.

A questão é enfrentada por Streck (2014), ao tratar do voluntarismo judicial. De acordo com o autor, o positivismo normativo de Hans Kelsen, ao fazer a cisão entre a ciência do direito (teoria pura) e o direito aplicado, cindiu também a própria interpretação da norma. Na moldura kelseniana, a interpretação tanto é um ato de conhecimento (quando descreve as normas de forma objetiva e neutra), como é um ato de vontade (quando aplica as normas ao caso concreto). Ao 
admitir que a aplicação da lei é um ato de vontade - fundado, portanto, em uma moral relativista -, a teoria pura do direito acabou ensejando, paradoxalmente, "um voluntarismo judicial sem precedentes" (STRECK, 2014, n.p.). Em outras palavras, a tentativa de transformar o estudo da norma jurídica em um sistema racional-conceitual levou ao resultado contrário: o império da vontade - agora a vontade do juiz ${ }^{3}$.

Chega-se, assim, à seguinte questão: como equacionar o princípio da legalidade e a discricionariedade, de forma a evitar que a vontade do administrador ou do juiz se transforme em arbitrariedade? Em outras palavras, ainda que se consiga eliminar o subjetivismo da atividade do administrador, é possível eliminá-lo da decisão judicial? Dois autores tratam essas questões de forma bastante inovadora.

Com fundamento na teoria estruturante do Direito ${ }^{4}$, Abboud (2014) defende a completa supressão do conceito de discricionariedade (administrativa e judicial), por meio de um método baseado em dois pressupostos: a concepção do direito como integridade e a tese da resposta correta. O autor parte do pressuposto de que o momento histórico em que está colocado o intérprete condiciona a sua interpretação. Assim, ao julgar o caso concreto, o juiz deve buscar reconstruir a história jurídica da comunidade (inclusive por meio dos precedentes judiciais) e eliminar critérios contraditórios, que poderiam levar a soluções diversas. O relativismo é afastado pela exigência de explicitação e justificação racional-discursiva das razões que levaram à escolha de uma determinada solução como a única correta (ABBOUD, 2014).

A tese da resposta correta, por sua vez, implica a análise do caso concreto à luz da teoria do direito, de forma a "destrinchar todos os conceitos e princípios jurídicos que incidem no caso juntamente com a moralidade política reinante na comunidade." (ABBOUD, 2014, p. 482). Para Abboud (2014), a norma jurídica não está contida na lei de antemão, mas surge a partir da interpretação, em um processo de linguagem que contrapõe o texto normativo aos fatos jurídicos:

7. O conceito de norma do paradigma pós-positivista não pode ser o mesmo do positivismo. Nessa perspectiva, para demonstrarmos os fundamentos do paradigma pós-positivista, será necessário analisarmos três pontos fundamentais: (a) a diferença entre texto e norma. (b) interpretação do direito deixa de ser ato revelador da vontade da lei ou do legislador; (c) a sentença deixa de ser processo silogístico: ou seja, as questões jurídicas não podem mais ser aplicadas por subsunção. (ABBOUD, 2014, p. 97)

Madalena (2016) traz contribuição importante ao debate ao distinguir as decisões de cunho político e as decisões administrativas/executivas. O autor recorre a Oliveira Santos (1919), cuja obra, no início do século passado, tratou das funções exercidas pelo Estado com base em dois 
poderes: o governamental e o administrativo. Madalena (2016) propõe a distinção entre os atos administrativos que materializam, de um lado decisões executivo-administrativas, e, de outro, escolhas políticas. As decisões administrativas executivo-administrativas, ou decisões administrativas stricto sensu, seriam integralmente controláveis, já que normatizadas prospectivamente pelo direito, bastando ao juiz interpretar o sentido da normatização por meio da "resposta hermeneuticamente adequada à Constituição" (MADALENA, 2016, p. 222). Quanto ao segundo tipo de decisões, o Poder Judiciário se limitaria a verificar os requisitos formais do ato e averiguar sua conformidade com a vontade política previamente manifestada. A decisão que determinou a construção do Viaduto Estaiado de Curitiba é considerada por Madalena (2016, p. 224) como uma decisão administrativa stricto sensu, pois não dependeria de uma escolha política. Esse caso será estudado detalhadamente na próxima seção.

\section{Decisões de política pública: atos administrativos stricto sensu ou escolhas políticas?}

O caso do Viaduto Estaiado de Curitiba é apresentado por Madalena (2016, p. 223-225) para ilustrar a aplicação da teoria crítica hermenêutica do Direito, desenvolvida por Lênio Streck, no âmbito da discricionariedade administrativa. Trata-se de obra contratada pela Prefeitura no âmbito do Plano de Aceleração e Crescimento PAC, como parte do conjunto de medidas financiadas com recursos da União para receber a Copa do Mundo de 2014, sediada no Brasil. O destaque dado ao viaduto - cuja construção teve início em 2012 e foi concluída em março de 2014 - deve-se ao fato de que seu valor foi orçado em $\mathrm{R} \$ 84,49$ milhões, correspondente ao custo de construção de mais de vinte viadutos comuns (MARCHIORI, 2012) e seu custo final chegou a R\$ 112 milhões (JUSTI, 2014).

Madalena (2016, p. 224) entende que a construção do viaduto foi uma decisão executivoadministrativa e estaria, portanto, sujeita a amplo controle jurisdicional quanto ao mérito do respectivo ato. De acordo com o autor, para definir a natureza administrativa ou política da decisão no caso concreto deve-se aferir se o ato que a materializa foi "normatizado prospectivamente pelo direito"- hipótese em que se trata de ato administrativo stricto sensu - ou "regulado aprioristicamente" por uma escolha política (MADALENA, 2016, p. 222). Percebe-se que, em ambos os casos, uma decisão política anterior condiciona o ato administrativo: seja uma decisão expressa por meio de um preceito constitucional e/ou norma legal e, portanto, instrumentalizada por meio de uma lei; ou uma decisão adotada no âmbito do Poder Executivo para viabilizar determinada 
política pública. Antes de aprofundar esse raciocínio, convém trazer alguns dados sobre o Viaduto Estaiado de Curitiba.

O elevado custo do viaduto é, evidentemente, o que mais chama a atenção. De acordo com o Dossiê Copa do Mundo e Violações de Direitos Humanos em Curitiba ${ }^{6}$, quase todo o valor foi repassado, a título de pagamento, para um único consórcio empresarial, o Consórcio CR Almeida e J. Malucelli (INSTITUTO AMBIENS DE EDUCAÇÃO, PESQUISA E PLANEJAMENTO, s.d.). A construção do viaduto foi mencionada no Relatório de Inspeção sobre as Obras de Mobilidade Urbana para a Copa do Mundo, elaborado pela Comissão de Fiscalização do Tribunal de Contas do Estado do Paraná, que indicou aumento dos gastos do erário em razão de deficiência no planejamento e execução das obras de preparação para o evento ${ }^{5}$. Entre as falhas no planejamento, o relatório refere-se à substituição de propostas econômicas por empreendimentos mais caros e cita como exemplo a construção do Viaduto Estaiado no lugar de uma trincheira ${ }^{7}$ (TRIBUNAL DE CONTAS DO ESTADO DO PARANÁ, 2016).

O Relatório de Inspeção foi aprovado pelo Tribunal de Contas Estadual, que determinou a tomada de contas extraordinária (TRIBUNAL DE CONTAS DO ESTADO DO PARANÁ, 2016). Em maio de 2018, o Tribunal aplicou multa a dois servidores públicos ${ }^{8}$ por falhas no planejamento e na execução do Viaduto Estaiado, entre elas a apresentação de valores superfaturados para execução da obra - no preço máximo de $\mathrm{R} \$ 85.370,734,12$, superior, portanto, ao valor apresentado pelo consórcio das empresas CR Almeida e J. Malucelli, no importe de R\$69.428.136,41 (TRIBUNAL DE CONTAS DO ESTADO DO PARANÁ, 2018). O Tribunal de Contas concluiu, ainda, que

95\% do total orçado não continham elementos justificadores dos preços dos serviços, tampouco a origem ou fonte empregada. Os orçamentos eram genéricos e insuficientes para avaliação e comparação. Devido a essas falhas, a equipe técnica concluiu que a falta de informações impossibilitou o julgamento objetivo e a seleção da proposta mais vantajosa para a administração. (TRIBUNAL DE CONTAS DO ESTADO DO PARANÁ, 2018)

Qualquer presunção extraída das notícias acima - inclusive a de que teria havido desvio de finalidade na contratação do Consórcio CR Almeida e J. Malucelli para a construção do Viaduto Estaiado - é um juízo a posteriori. Seria possível, ao analisar o caso em 2011, quando foi lançado o edital de concorrência da obra, concluir pela ausência de motivação válida para a construção do viaduto? A resposta à indagação passa por uma questão antecedente: a decisão da Prefeitura de construir um viaduto "estaiado" 9 para fazer a ligação rodoviária de um lado ao outro da Avenida Torres pode ter seu mérito apreciado pelo Poder Judiciário? 
Ao invés de construir o Viaduto Estaiado, a Prefeitura poderia ter optado por uma solução mais simples, como a execução de uma trincheira, com enorme redução no custo da obra. Edson Navarro Tasso, auditor de controle externo do Tribunal de Contas da União, afirmou em seu blog, em 04/04/2012, ao comentar a construção do Viaduto Estaiado:

[...] na mesma Avenida das Torres, aproximadamente dois quilômetros sentido centro da cidade, o mesmo edital propõe a construção de uma trincheira que soluciona o mesmo problema de travessia existente na Rua F. H. dos Santos. Segundo consta de um pequeno texto das esparsas especificações do edital, a trincheira permitiria a passagem de cinco faixas de rolamento e estaria orçada em $\mathrm{R} \$ 2.031 .247,00$.

[...] É evidente que daria para construir trincheira semelhante no cruzamento da Rua Francisco H. dos Santos com custo aproximado entre 2 a 4 milhões de reais. Uma alternativa, a mais viável, seria elevar o leito da Av. das Torres e construir trincheira para passagem da Av. Francisco H. dos Santos. (TASSO, 2012, n.p.)

Consulta ao edital de concorrência CN/081/2011 - CN/081/2011-SMOP/OPP (CURITIBA,SECRETARIA MUNICIPAL DE OBRAS PÚBLICAS, 2011) confirma a informação de que a trincheira realizada na Rua Guabirotuba, foi orçada no valor de $\mathrm{R} \$$ 2.031.247,00. Para justificar a escolha de construir um viaduto "estaiado" - a despeito da enorme diferença de custo entre ambas as obras de arte - a Prefeitura Municipal apresentou, segundo Madalena (2016), duas justificativas: o interesse em erigir uma obra de arte especial cujas características arquitetônicas fossem suficientemente singulares para associá-lo à imagem de Curitiba e permitissem criar um ponto turístico capaz de atrair visitantes à cidade; e a necessidade de preservar abaixo do viaduto um grande vão livre para a passagem de um Veículo Leve sobre Trilhos (VLT) ${ }^{10}$.

Cabe averiguar se tal decisão foi uma decisão executivo-administrativa (normatizada prospectivamente pela lei ou pela Constituição) ou determinada por uma escolha política (regulada aprioristicamente por um ato de governo), conforme terminologia proposta por Madalena (2016). Para concluir que a decisão foi executivo-administrativa, Madalena argumenta que a Constituição, ao estatuir em seu artigo 3o, os objetivos fundamentais da República Federativa do Brasil - dentre eles a redução das desigualdades sociais - já ofereceria, de antemão, a prescrição normativa da conduta a ser adotada pela Administração. Como esses objetivos não podem ser relativizados, ele afirma, o administrador estaria vinculado à escolha da obra de menor custo - independentemente das considerações acerca do estímulo ao turismo ou da conveniência de se manter um vão livre para a passagem futura de um VLT. 
Para análise do argumento apresentado por Madalena (2016), é importante distinguir os atos administrativos stricto sensu dos atos administrativos realizados no exercício da atividade política. Rua (1998, p. 232) define as atividades políticas (politics) como "o conjunto de procedimentos formais e informais que expressam relações de poder e que se destinam à resolução pacífica dos conflitos quanto a bens públicos". As atividades políticas dão origem a decisões e ações do Governo que refletem valores da sociedade. Esses valores, por sua vez, são hierarquizados de acordo com as relações de poder entre os atores políticos e constituem, no seu conjunto, as políticas públicas (policies). Pode-se dizer, assim, que as atividades políticas (politics) definem quais são os valores considerados relevantes e os objetivos a serem perseguidos pelo Estado, enquanto as políticas públicas (policies) compreendem as ações estrategicamente adotadas e decisões políticas necessárias à realização desses valores e objetivos. É importante compreender que:

grande parte da atividade política dos governos se destina à tentativa de satisfazer as demandas que thes são dirigidas pelos atores sociais ou aquelas formuladas pelos próprios agentes do sistema político, ao mesmo tempo que articulam os apoios necessários. Na realidade, o próprio atendimento das demandas deve ser um fator gerador de apoios - mas isto nem sempre ocorre, ou, mais comumente, ocorre apenas parcialmente. De qualquer forma, é na tentativa de processar as demandas que se desenvolvem aqueles "procedimentos formais e informais de resolução pacífica de conflitos" que caracterizam a política. (RUA, 1998, p. 234)

Os objetivos da nossa República Federativa, expressos no artigo 3o da Constituição Federal, traduzem o resultado da atividade política dos diferentes atores que se mobilizaram durante a constituinte. Tais objetivos representam os valores considerados relevantes pela República brasileira e orientam as ações e decisões do Governo Federal, Estadual e Municipal. Tais ações e decisões, por sua vez, não estão prescritas normativamente na Constituição, mas resultam de uma série de procedimentos formais que constituem as diferentes políticas públicas adotadas no âmbito de cada esfera governamental.

Compreende-se, assim, que decisão de construir ou não o Viaduto Estaiado não está prescrita normativamente da Constituição, isto é, não decorre da mera interpretação do seu artigo 3ำ, assim como não é prevista na legislação ordinária. Ao contrário, ela é uma escolha política adotada no âmbito de uma determinada política pública, no caso, a política urbana. Isso não quer dizer, contudo, que o ato administrativo que materializa essa escolha não possa ser controlado pelo Poder Judiciário com relação ao seu mérito.

Para avançar nesse raciocínio, é interessante voltar ao pensamento de Santos (1919), especialmente quando ele distingue, como lembra Madalena (2016), os atos administrativos 
necessários para lidar com situações de calamidade - para os quais é necessário o exercício do poder discricionário, dada a impossibilidade de serem previstos pelo legislador - e os atos administrativos necessários para combater a desigualdade social, esses sim, vinculados a expressa previsão legal. Interessa aqui não tanto a distinção feita por Santos (1919), mas sua afirmação de que o Estado exerce "poder discricionário" quando seus atos têm por objetivo proteger a sociedade dos males imprevistos, e, portanto, para os quais o legislador não prescreveu nenhuma conduta (SANTOS, 1919).

Ao atuar em defesa da coletividade em condições normais, o Estado não poderia, segundo Santos (1919), ir além do necessário para garantir a segurança pública e particular. Contudo - e este é o ponto interessante -, em determinadas situações de emergência, como as de calamidade pública, o Poder Público deveria atuar com base no seu poder discricionário - justamente porque em tais casos não existem normas legais que permitam sanar o perigo ou diminuir o dano imediato. Nessas situações, o governo deveria agir de acordo com seu critério e as circunstâncias do caso concreto. Percebe-se, pois, a preocupação de Santos (1919) com a reserva de poderes deixada ao administrador para decidir com base no poder discricionário, na ausência de normas legais prescritivas (e, a contrario sensu, com a estrita vinculação do ato administrativo à lei e à Constituição).

O raciocínio desenvolvido por Santos (1919) permite concluir que, em condições normais - isto é, na ausência de calamidade pública ou outra situação de emergência - a atividade do administrador está vinculada a uma decisão anterior, seja ela posta em uma norma legal ou oriunda de escolha política, realizada no âmbito de determinada política pública. É evidente que tais escolhas devem guardar consonância com os valores e objetivos constantes da Constituição, daí porque o primeiro ponto a ser apreciado no controle judicial dos atos que materializam escolhas políticas diz respeito à sua adequação às prescrições contidas nas normas constitucionais e legais.

O segundo ponto a ser verificado no controle judicial é a vinculação do ato administrativo à escolha política previamente realizada. É interessante lembrar que os procedimentos e decisões de cada uma das políticas públicas decorrem de planejamento estatal, atividade obrigatória do Estado conforme disposto nos artigos 174 e 165 da Constituição, que estabelecem, respectivamente, o dever do Estado de planejar a atividade econômica do país e a obrigatoriedade do plano de investimentos plurianual, conforme acentuam Costa e Clark (2012):

o Texto da Constituição brasileira de 1988 impõe ao Estado, como poder/ dever, de agir de forma planejada em nossa perversa realidade espacial, social e produtiva, também, em outros tantos comandos, tais como: a União elaborará e executará planos nacionais e regionais de ordenação territorial e 
de desenvolvimento socioeconômico (art. 21, IX da CR/88) e planejará a política agrícola nacional (art. 187, caput da CR/88); os Estados instituirão e planejarão as regiões metropolitanas (art. 25, parágrafo terceiro da CR/88); os municípios planejarão o ordenamento territorial, o desenvolvimento e a expansão urbana, bem como o bem estar dos munícipes, mediante o Plano Diretor, sendo ele obrigatório para aqueles que possuem mais de 20 mil habitantes (arts. 30, VIII e 182 da CR/88). (COSTA; CLARK, 2012, n.p.)

De acordo com Costa e Clark (2012), o planejamento é o processo pelo qual o Estado define racionalmente os meios de intervenção nas atividades dos particulares e a melhor forma de investir os recursos públicos para cumprir os preceitos constitucionais. O planejamento estatal, por sua vez, se materializa em planos, que trazem diagnósticos da situação econômica (recursos disponíveis) e orientações quanto às ações consideradas necessárias pelos técnicos e pela sociedade para alcançar os objetivos da nossa Constituição (COSTA; CLARK, 2012) ${ }^{11}$.

No âmbito da política urbana, o planejamento se instrumentaliza por meio do plano diretor, previsto no artigo 182 da Constituição Federal ${ }^{12}$. De acordo com o Estatuto da Cidade, o plano diretor das cidades com mais de 500.000 habitantes deve conter um Plano de Transporte Urbano Integrado, ou, no mínimo, previsão de elaboração de um plano independente nesse sentido (artigo 41, § 2o). Além disso, a Lei de Diretrizes da Política Nacional de Mobilidade Urbana determina que os municípios com mais de 20.000 habitantes devem elaborar plano de mobilidade urbana, integrado e compatível com o seu plano diretor (Lei 12.587/2012, artigo 24, § 1으).

Um dos requisitos para a validade do plano diretor e plano de mobilidade urbana é a participação da sociedade civil na sua formulação. De acordo com o Estatuto da Cidade (Lei 10.257/2001, artigo 2o, inciso II, c/c artigos 43, 44 e 45), tanto o plano diretor como o plano de mobilidade urbana devem contemplar, no seu processo de elaboração e na fiscalização de sua implementação, canais de participação da sociedade civil, na forma de audiências públicas e debates com a população e associações representativas dos vários segmentos da comunidade ${ }^{13}$.

A política de turismo, por sua vez, consubstancia fator de desenvolvimento social e econômico do País, conforme dispõe o artigo 180 da Constituição Federal. Embora esse dispositivo esteja no capítulo que regula a ordem econômica, sua regulamentação pela Lei 11.771/2008 deixa claro que são também objetivos da política de turismo criar e implementar empreendimentos destinados às atividades de expressão cultural (artigo 5으, inciso VII) e promover a atividade turística como veículo de educação e interpretação ambiental (artigo 5o, inciso VIII). A lei 11.771/2008 estabelece o Plano Nacional de Turismo, que deverá ter suas metas e programas revistos no mínimo a cada 4 (quatro) anos, em consonância com o PPA (artigo 6º, parágrafo único). 
Todos esses instrumentos de planejamento devem ser elaborados democraticamente, isto é, com a participação de todos os atores políticos que disputam a alocação de bens e recursos públicos ${ }^{14}$. As escolhas políticas materializadas nos planos são, portanto, resultado da capacidade de mobilização dos atores políticos de forma a interferir na produção das políticas públicas. Daí porque o conteúdo dessas escolhas não pode ser revisto pelo Poder Judiciário, a quem falta legitimidade constitucional para exercer atividade política ${ }^{15}$. Contudo, cabe ao Judiciário verificar se os atos administrativos adotados para implementar as políticas públicas guardam consonância com as escolhas políticas realizadas durante a atividade de planejamento do Estado e materializadas nos seus diversos planos de ação.

$\mathrm{Na}$ tarefa de verificar se o ato administrativo resultante do poder discricionário atende aos dois pontos acima indicados - a adequação às normas constitucionais e legais e a vinculação à escolha política materializada nos planos de governo - é importante recordar o papel do Poder Judiciário na realização do Estado Democrático de Direito. Mais do que a simples garantia dos direitos sociais assegurada pelo Estado Social - o Estado Democrático de Direito estabelecido na nossa Constituição pressupõe, segundo Streck (2005), a participação de todos os grupos da sociedade, inclusive os marginalizados, no processo político. Não se trata de mera participação formal, mas de interferência na produção das políticas públicas tanto na esfera pública como nos canais de participação instituídos pelo Estado para exercício da democracia direta e participativa, conforme previsto no artigo 1o, parágrafo único, da Constituição Federal.

Nesse contexto, ganha especial relevância a hermenêutica constitucional. A atividade hermenêutica pode realizar-se por meio de duas posturas. A primeira delas é adotada por aqueles que ainda raciocinam de acordo com os paradigmas jurídicos do Estado Moderno, no modelo liberalindividualista, e optam por uma hermenêutica de bloqueio constitucional ${ }^{16}$. A segunda postura, ao contrário, busca dar efetividade ao texto constitucional mediante procedimentos racionais de justificação. A próxima seção analisará os motivos apresentados pela Prefeitura de Curitiba para a construção do Viaduto Estaiado com base na segunda postura hermenêutica.

\section{O caso do Viaduto Estaiado: controle da discricionariedade administrativa via planejamento}

Como visto na seção anterior, os atos administrativos condicionados por escolhas políticas podem sofrer controle judicial para verificação da sua adequação: (i) às normas constitucionais e legais (que, em última análise, materializam escolhas políticas do Poder Legislativo); (ii) às decisões adotadas pelo Poder Executivo no processo de formulação de suas diferentes políticas públicas, 
instrumentalizadas em planos de governo. Cabe, a esta altura, analisar os argumentos trazidos por Madalena (2016) para aferir a validade do ato administrativo que culminou com a construção do Viaduto Estaiado.

De acordo com Madalena (2016), a Prefeitura teria apresentado dois motivos para justificar a elevação do custo da obra: o interesse em atrair atividades turísticas e, assim, estimular a economia do município; e a necessidade de deixar um vão livre para a passagem de um futuro VLT sob o viaduto. Com relação à primeira das justificativas, Madalena (2016) entende que a decisão de contratar uma obra com arquitetura singular para estimular as atividades turísticas do município vai de encontro ao objetivo de redução das desigualdades sociais, previsto no artigo 3o da Constituição Federal (MADALENA, 2016, p. 224). Contudo, alguém poderia se opor a esse raciocínio, afirmando que a redução das desigualdades sociais demanda investimentos em serviços públicos, que, por sua vez, precisam ser financiados pelo erário. O turismo é uma atividade econômica que gera empregos e arrecada receita tributária para o Município. Nesse sentido, é de se registrar que a imagem do Viaduto Estaiado se assemelha à da Ponte Estaiada de São Paulo, anunciada como um novo cartão postal daquela cidade quando foi entregue à população em 2008.

Não se pretende discutir aqui a transformação das cidades contemporâneas em "cidades espetáculo" ou o problema de homogeneização dos espaços urbanos, tão bem percebido por Harvey (2006, 2012). O que interessa para o propósito deste trabalho é o fato de que a Ponte Estaiada - que está localizada próxima aos mais importantes centros empresariais da cidade e a hotéis bastante luxuosos - associa a cidade de São Paulo à imagem de metrópole empresarial, atraindo, assim, o turismo de negócios. Uma consulta ao atual Plano Municipal de Turismo de Curitiba revela que 40,5\% dos turistas visitam Curitiba em viagens a negócios ou motivados por questões profissionais. Percebe-se, assim, que o primeiro dos critérios apontado por Madalena (2016) para a solução do problema demandaria análise aprofundada - a ser produzida por meio de prova técnica - da capacidade do Viaduto Estaiado de gerar receitas por meio do incremento do turismo na cidade.

Veja-se que não se está a justificar a destinação de mais de cem milhões de reais à criação de um ponto turístico que poderia, em tese, associar a imagem de Curitiba a uma metrópole empresarial. O que se pretende é, nos moldes do método proposto por Abboud (2014), realizar um exercício de justificação racional-discursiva para identificar critérios contraditórios de solução do problema jurídico e afastar as contradições na busca da decisão correta.

Com relação à segunda justificativa, qual seja, a de que o custo exorbitante da obra decorreria da necessidade de deixar um vão livre para passagem de um VLT, Madalena (2016) conclui que a falta de previsão de implantação do VLT no PPA do município de Curitiba torna a justificativa 
da Prefeitura incoerente (2016, p. 225). Para o autor, a "necessária coerência e integridade das decisões administrativas" leva à conclusão de que "a resposta correta provida pelo Direito e que deve(ria) vincular a atividade administrativa para o caso, é a não construção da obra comprometendo o montante de recursos que comprometeu" (MADALENA, 2016, p. 225).

A respeito, é preciso ter em mente que o PPA do Município, então em vigor, era a Lei 13.378/2009, que realmente não previa a implantação de um VLT no quadriênio 2010/2013. As pesquisas realizadas até então indicavam que o metrô seria a alternativa mais adequada às especificidades de Curitiba:

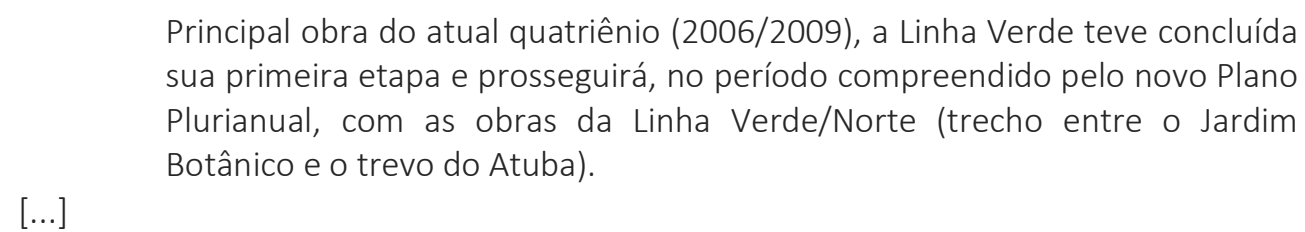

As pesquisas e sondagens realizadas pelo IPPUC indicam o metrô como alternativa mais adequada para as especificidades de Curitiba, opção endossada por estudo de viabilidade técnica e econômica feito pela CBTU (Companhia Brasileira de Trens Urbanos), empresa do Governo Federal. Documentos e estudos finais definirão aspectos técnicos, conceituais, funcionais e operacionais do sistema, métodos construtivos e tecnologia do material rodante. (PPA de Curitiba 2009-2013)

Contudo, já em maio de 2016, sob a vigência do novo PPA (Lei 14.371/2013), a Prefeitura de Curitiba publicou um Procedimento de Manifestação de Interesse (concurso de ideias entre empresas interessada que serve de base para futura licitação) direcionado à implantação e operação de linhas de transporte público com acionamento elétrico, a saber, Veículo Leve sobre Pneus (VLP) e VLT (PREFEITURA MUNICIPAL DE CURITIBA, 2016).

Segundo a Agência de Notícias da Prefeitura Municipal de Curitiba (2016), os veículos eletromóveis têm a vantagem de não serem poluentes, oferecerem maior conforto e silêncio e aumentarem a capacidade de transporte, pois operam com três ou seis unidades conectadas. A capacidade desse meio de transporte pode chegar a 25 mil passageiros por hora e o custo é estimado em 75\% (setenta e cinco por cento) a menos do que o de um metrô. A Prefeitura afirmou, ainda, que pretende incluir os eletromóveis em cinco diferentes trechos da cidade: um deles é o trecho Aeroporto - Centro Cívico, que pode seguir dois traçados: Centro Cívico - Boqueirão, via Marechal Floriano; ou Centro Cívico - Centro de Feiras, via Avenida das Torres, onde está localizado, na confluência com a Avenida Coronel Francisco Heráclito dos Santos, o Viaduto Estaiado (PREFEITURA MUNICIPAL DE CURITIBA, 2016). 
É certo que tais elementos não estavam disponíveis quando da primeira análise do caso. Além disso, a previsão de implantação do VLT no trecho Centro Cívico - Centro de Feiras não é suficiente para se concluir pela validade do motivo apresentado pela Prefeitura de Curitiba, até porque não se chegou a verificar se o traçado da linha Aeroporto - Centro Cívico via Avenida das Torres passa efetivamente pelo vão livre do Viaduto Estaiado. A despeito disso, a notícia traduz a dinamicidade de que se reveste a atividade administrativa, muito bem pontuada por Faria (2016), quando afirma que, em tempos de globalização econômica, a Administração Pública precisa atuar de forma mais dinâmica e eficiente para atender às necessidades da sociedade.

Em outras palavras, uma decisão administrativa que, em juízo de prognose, deixa um vão livre para a passagem de um meio de transporte - ainda que não previsto no PPA do Município não é de ser afastada de pronto por falta de motivação. Ao contrário, parece ir ao encontro dos princípios de planejamento e integridade, expressamente citados por Madalena (2016, p. 225), segundo os quais não se deve descartar, em futuras intervenções urbanísticas, o que já foi realizado no passado. Como se sabe, o PPA é um plano de médio prazo que estabelece diretrizes, objetivos e metas a serem seguidos pelo Governo no período de 4 (quatro) anos. Qualquer prognose em relação a um período superior a quatro anos não aparece no PPA, mas nem por isso deve ser descartada, sob pena de violação ao princípio da eficiência da Administração Pública, previsto no artigo 37 da Constituição Federal

Portanto, ao invés de descartar de imediato a justificativa apresentada pela Prefeitura, caberia submetê-la a análise técnica para avaliar, por exemplo: a) se, diante da eventualidade de implantação de um VLT, a construção do viaduto, ao invés da trincheira, teria sido a melhor solução; b) se, para a passagem de um futuro VLT, seria realmente necessário manter um vão livre nas dimensões em que foi previsto para a construção do viaduto; c) se a opção pela construção de um VLT, no futuro, não poderia considerar um traçado alternativo para evitar o cruzamento com o viaduto. Tais questões (e, eventualmente outras surgidas no processo judicial) teriam de ser respondidas por peritos e submetidas ao contraditório, para só então se chegar à conclusão acerca da conveniência de se adotar o Viaduto Estaiado como solução técnica para fazer a ligação rodoviária na Avenida Torres ${ }^{17}$.

Observe-se que o motivo, nesse caso, vincula a Administração a uma única escolha possível, determinada tecnicamente. Embora alguns autores ainda defendam a existência de discricionariedade técnica, a maior parte da doutrina contemporânea entende que, nos casos em que a melhor escolha da Administração deve ser determinada por meio de conhecimentos técnicos, não há discricionariedade por parte do administrador. Concorda-se com esse posicionamento, já 
que, como acentua Faria (2016, p. 150), nessas situações "o elemento objeto de escolha é o estritamente técnico. De modo que no campo da técnica não se pode admitir escolha de conveniência ou oportunidade, mas apenas a adoção da norma técnica apropriada para determinado caso".

Conclui-se, assim, que os dois critérios apontados por Madalena para aferir a validade do ato administrativo em análise dependem de conhecimentos técnicos. Contudo, a partir do raciocínio desenvolvido na segunda seção, é possível chegar a um terceiro critério. A construção de um viaduto é obra de política urbana, mais especificamente de política setorial de mobilidade urbana. No caso do Viaduto Estaiado, ela também integra a política de turismo do município. Como visto, qualquer obra de mobilidade urbana deve estar prevista no plano de mobilidade urbana do Município, que, por sua vez, deve ser compatível com o plano diretor do município. Além disso, considerando-se o valor a ser dispendido, a obra de construção de um viaduto deve constar do PPA do Município, que, por sua vez, deve ser compatível com o plano diretor (artigo 40, § 1o da Lei 10.257/2001) . Finalmente, se a obra for planejada para criar ponto turístico de forma a atrair o turismo deve estar prevista também no plano de turismo municipal. Assim, embora não se possa exigir que a futura implantação de um VLT no trecho que cruza o Viaduto conste do PPA de Curitiba para o período de 2009-2013, a própria construção do Viaduto Estaiado deveria, em princípio, constar não só do plano diretor, como do plano de mobilidade urbana e do PPA do Município para o período de 2009-2013.

Nesse ponto, é preciso situar o ato administrativo que autorizou a construção do Viaduto Estaiado no contexto em que foi praticado: como mencionado linhas atrás, o viaduto foi contratado pela Prefeitura como parte do conjunto de obras financiadas com recursos da União e destinadas a receber a Copa do Mundo de 2014. Conforme analisado por Costa e Clark (2012), o curto período transcorrido entre outubro de 2007 - data em que o Brasil foi escolhido como país sede - e a realização do evento dificultaram a elaboração de planejamento que permitisse racionalizar o uso dos recursos públicos e privados com o fim de atender às necessidades da sociedade brasileira. Segundo os autores, a decisão de sediar a Copa do Mundo de 2014 levou à ausência de planejamento estatal, em prejuízo de "imprescindíveis políticas públicas estruturais fundamentais à materialização da Constituição brasileira de 1988" (COSTA E CLARK, 2012, p. 3.803).

Independentemente do acerto ou não da decisão, o certo é que, escolhido o Brasil como sede da Copa de 2014, os atos administrativos direcionados à realização do evento passaram a ser regulados por essa decisão e vinculados ao seu conteúdo ${ }^{18}$. Em outras palavras: a alocação de recursos financeiros para as obras da Copa de 2014 decorreu de escolha política - feita pela República Federativa - de se candidatar a país-sede dos jogos da Copa de 2014. Diante do escasso 
tempo disponível para os preparativos, procedimentos inerentes ao planejamento urbano e essenciais à concretização dos objetivos da política urbana nacional, como os procedimentos de gestão democrática, foram contornados.

A rejeição de parte dos moradores de Curitiba à construção do Viaduto Estaiado, noticiada por Comin (2017) ${ }^{19}$, talvez reflita o fato de que não foram realizadas consultas públicas para informar e ouvir sugestões da população sobre a construção do viaduto. O Dossiê "Copa do Mundo e Violações de Direitos Humanos em Curitiba" revelou que o único esclarecimento divulgado de antemão pela Prefeitura foi a respeito da licitação da obra. Além de violação ao direito de informação, o Dossiê registra que não há notícia de participação dos moradores e empresários da região na realização do projeto, na definição das desapropriações e na forma de execução das obras. Evidentemente, a falta de informação e de participação da comunidade na formulação da política urbana afronta o princípio da gestão democrática (Lei 10.257/2001, artigo 2o, inciso II, c/c artigos 43, 44 e 45) e privilegia o atendimento dos interesses do setor de construção civil, único ator político a interferir na escolha política que culminou com a construção do Viaduto Estaiado. Conforme ressalta Brandenburg (2014):

\begin{abstract}
Para dar início à obra do Viaduto Estaiado e demais obras na Av. Comendador Franco quatro decretos de desapropriações foram elaborados, somando um total de 43 imóveis declarados pela prefeitura como de utilidade pública (PORTAL DA TRANSPARËNCIA, 2013). Nenhuma das intervenções envolveu participação democrática da população, estudo de impacto de vizinhança ou qualquer outro mecanismo para distribuir os ônus e os bônus dos impactos do projeto. Portanto, fica claro que acabar as obras no prazo determinado para realização dos jogos da Copa de 2014 é prioridade, em detrimento dos interesses da população local. Destaca-se, que além da população imediatamente removida, com a possível valorização imobiliária do entorno imediato às obras, pode haver deslocamento da população original também a longo prazo. (BRANDENBURG, 2014, p. 240)
\end{abstract}

Importante ressaltar que a decisão de construir o Viaduto Estaiado para resolver um problema de mobilidade urbana na Avenida das Torres não constou de qualquer planejamento prévio da Prefeitura de Curitiba. Comin (2017) ressalta que foi elaborada, em 2010, uma matriz de responsabilidades com as obras a serem realizadas pelas cidades-sede. Segundo a autora, as obras elencadas na matriz de responsabilidades de Curitiba já eram previstas nos planos de ação municipais. Contudo, à medida em que o evento se aproximava, os custos de determinadas obras se elevaram e algumas propostas que apareciam na matriz de responsabilidades de 2010 acabaram 
sendo excluídas. Por outro lado, obras - que não constavam da matriz de responsabilidades - foram realizadas, como a obra do Viaduto Estaiado e o Parque da Imigração Japonesa.

Nesse ponto parece estar a solução do problema. É certo que a falta de previsão, no PPA de 2009-2013, da implantação de VLT no trecho que passaria, segundo a Prefeitura, sob o viaduto não é suficiente para afastar o motivo apresentado para o alto custo da obra. Contudo, a não inclusão do próprio Viaduto Estaiado na matriz de responsabilidades das obras da Copa joga por terra todas as justificativas apresentadas pela Prefeitura de Curitiba.

De fato, diante da premência de se preparar Curitiba para sediar alguns dos jogos de futebol da Copa de 2014, impunha-se ao administrador adotar as medidas necessárias para adequar a estrutura viária da cidade às demandas geradas pela realização desse campeonato mundial. A decisão de sediar a Copa - assim como a decisão de Curitiba de se candidatar à cidade-sede - é decisão política e, portanto, excluída do controle jurisdicional. Evidentemente, não se pode exigir que as obras de mobilidade para a realização da Copa do Mundo de 2014 constassem do PPA de Curitiba para o período 2009-2013, uma vez que, à época da elaboração do plano, a cidade sequer havia sido escolhida cidade-sede para alguns jogos do campeonato mundial.

Contudo, a decisão de construir o Viaduto Estaiado no lugar de uma trincheira e de atribuirIhe características que resultaram no encarecimento desproporcional da obra não está necessariamente vinculada à escolha política de sediar a Copa de 2014. Em outras palavras: embora fosse necessário realizar uma obra viária para resolver o problema de mobilidade urbana na Avenida Torres, a construção do Viaduto Estaiado foi uma escolha entre várias opções possíveis. Nesse contexto, o fato de que o viaduto não consta da matriz de responsabilidades da Copa do Mundo ao contrário das demais obras - demonstra a falta de vinculação entre o ato que autorizou sua construção e as escolhas políticas anteriormente adotadas.

Ainda que se desvincule a construção do Viaduto Estaiado do contexto em que ela se insere, isto é, como obra de mobilidade necessária à realização dos jogos da Copa do Mundo de 2014, as justificativas apresentadas pela Prefeitura de Curitiba para construção do Viaduto Estaiado colidem com normas constitucionais e legais. Isto porque as ações necessárias à implementação da política setorial de mobilidade urbana - entre elas a construção de viadutos - deve estar prevista no respectivo plano. Se a obra envolver dispêndio de recursos públicos para incremento das atividades turísticas, deve estar prevista também no plano de turismo municipal. Em ambos os casos, deve constar do PPA municipal. No caso de obras que comportem intervenção arquitetônica de impacto igual ao do Viaduto Estaiado (com necessidade de desapropriação de imóveis e redesenho do traçado urbanístico da região), precisam também ser incluídas no plano diretor. Esses instrumentos 
de planejamento devem contar obrigatoriamente com a participação de todos os atores envolvidos na política urbana.

O planejamento tem papel fundamental no controle dos atos administrativos discricionários, na medida em que justifica os investimentos públicos realizados pelo Estado por meio da demonstração das expectativas de resultados positivos e negativos de cada uma das ações propostas (COSTA; CLARK, 2012). Além disso, o planejamento das políticas públicas (urbana, de turismo, de meio ambiente etc.), se realizado de forma democrática e participativa, reflete o embate de interesses dos atores políticos que se mobilizam tanto nas instâncias de participação democrática organizadas na estrutura estatal, como fora dela, na esfera pública. O processo de participação social - que garante transparência ao planejamento - mostra-se fundamental para dar voz aos atores tradicionalmente excluídos da política nacional e, assim, concretizar os direitos sociais garantidos na Constituição.

Por meio da análise acima, conclui-se que: a) a decisão da Prefeitura de fazer a ligação rodoviária entre os dois lados da Avenidas das Torres é condicionada por escolha política anterior, qual seja, a de sediar a Copa do Mundo de 2014, e, portanto, apenas pode ser apreciada quanto à sua adequação às normas constitucionais e legais e à escolha anteriormente realizada; b) a opção por construir um viaduto para fazer essa ligação, ao invés de uma trincheira (de custo várias vezes menor), é uma decisão técnica, e portanto, não discricionária; c) a decisão de construir o Viaduto Estaiado, a despeito da obra não estar prevista quer na matriz de responsabilidades da Copa do Mundo quer nos planos de mobilidade urbana, de turismo, no plano diretor ou no PPA municipais, revela-se inadequada à escolha política anteriormente realizada (sediar os jogos da Copa), além de contrariar as normas legais e constitucionais, sendo, portanto, uma decisão inválida.

\section{Conclusão}

O artigo analisou o caso do Viaduto Estaiado, em Curitiba, cujo custo exorbitante foi justificado pela Administração Pública Municipal alicerçada em dois motivos: o primeiro deles é a arquitetura singular da obra, destinada a estimular o turismo na cidade; o segundo, a necessidade de deixar um vão livre sob a obra para passagem de um linha de VLT futuramente.

Sustentou-se que a revisão do mérito dos atos administrativos praticados no âmbito de políticas públicas implica substituir decisões tomadas no exercício da atividade política - e, portanto, resultante do conflito de interesses de diversos atores - pela decisão do juiz, que não detém legitimidade representativa. Contudo, cabe ao Poder Judiciário, nesses casos, aferir se o ato 
administrativo praticado guarda conformidade com a decisão política à qual está vinculado e com as normas constitucionais e legais.

Com relação ao ato administrativo que culminou com a construção do Viaduto Estaiado, demonstrou-se que não se trata de decisão executivo-administrativa, mas resultante de escolha política anterior, qual seja, a decisão do Município de sediar jogos da Copa do Mundo de 2014.

A análise dos critérios utilizados por Madalena (2016) para afirmar que o ato administrativo em questão não fora melhor escolha da Administração revelou que as justificativas apresentadas pela Administração não podem ser afastadas sem estudo técnico acerca da capacidade do Viaduto Estaiado de atrair turismo para a região ou da conveniência de se preservar um vão livre sob o viaduto para passagem, no futuro, de uma linha de VLT. Tal constatação afasta a existência de discricionariedade, já que os autores se alinham à posição dos doutrinadores que não admitem discricionariedade técnica.

Apresentou-se, ainda, um terceiro critério, qual seja, a obrigatoriedade de previsão da construção do Viaduto nos planos municipais. Verificou-se que o Viaduto Estaiado não consta da matriz de responsabilidades de 2010 para a realização das obras da Copa ou do PPA 2009/2013, o que demonstra a violação da norma constitucional que exige prévio planejamento para dispêndio de recursos públicos (artigo 174 c/c artigo 165 da Constituição Federal). Além disso, constatou-se que o viaduto não foi previsto no plano de mobilidade urbana ou no plano diretor do município, o que revela descumprimento das normas constitucionais e legais que determinam a obrigatoriedade do planejamento da política urbana (artigo 30, inciso VIII c/c 182, § 1으, da Constituição e artigo 41, § 2은 da Lei 10.257/2001) e da política de mobilidade urbana (artigo 24, § 1으, da Lei 12.587/2012). Por último,

Finalmente, conclui-se que a falta de previsão do Viaduto Estaiado nos referidos planos: contraria as normas que prescrevem a obrigatoriedade do planejamento participativo (Lei 10.257/2001, artigo 2으. inciso II, c/c artigos 43, 44 e 45); favorece a prevalência dos interesses do capital em detrimento dos interesses da comunidade; induz o dispêndio desnecessário de recursos públicos, que poderiam ser investidos de melhor forma de acordo com os objetivos das políticas públicas conduzidas pelo Município nos quatro planos de governo (planos de mobilidade urbana, de turismo, plano diretor e PPA).

O atendimento aos princípios da gestão democrática e do planejamento do desenvolvimento urbano, por outro lado, dão transparência à atividade política, na medida em que exigem que as escolhas do governo sejam justificadas e permitem a participação dos diversos atores políticos no processo de implementação da política urbana. 
NOTAS

1.0 gérmen do conceito de interesse público é a ideia de bem comum, desenvolvida por John Locke. Diante da constatação de que o Parlamento - que representava a vontade popular - não poderia jamais prever todas as possibilidades de atuação do governante, Locke propunha que, na falta de regramento legal - e mesmo em contrariedade à lei posta - a conduta do governante fosse sempre norteada pelo "bem da sociedade" (MADALENA, 2016, p. 33).

2. Madalena (2016) trata da forma como a discricionariedade administrativa é utilizada para blindar os atos administrativos contra a revisão jurisdicional. A blindagem permite, no seu entender, que o administrador justifique a priori sua conduta, utilizando-se do conceito de interesse público - que funciona como um verdadeiro curinga - e conferindo ao ato administrativo uma forma aceita pela Constituição, ainda que seus objetivos sejam contrários aos do texto constitucional. Essa prática interessa especialmente ao capital nacional e internacional, já que lhes possibilita manipular de forma eficiente a burocracia estatal de forma a atender seus próprios interesses.

3. Nesse sentido, Streck (2005) afirma que os operadores do Direito também estão sujeitos à ideologia do paradigma neoliberal, de caráter individualista, que funciona como contraponto das políticas de bem-estar social preconizadas na nossa Constituição. Daí porque, no seu entender, passados trinta anos da promulgação da Constituição, que garante os direitos sociais de forma ampla, tenha falhado - sob o beneplácito do Poder Judiciário - a tentativa de concretização do Estado Social.

4. Para a teoria estruturante do Direito, formulada por Friedrich Mülller no período pós-2a Guerra Mundial, a linguagem - ao contrário do raciocínio matemático - não lida apenas com abstrações, mas é produzida a partir da realidade fática. Isto significa que os significados jurídicos não estão colocados de antemão na norma jurídica, mas são construídos no momento em que o texto normativo é interpretado diante de um caso concreto: "Deste modo, o texto da norma não é a própria norma jurídica, não é elemento conceitual da norma jurídica, mas configura o dado de entrada (input) mais importante ao lado do caso a ser decidido juridicamente, no processo de concretização da norma." (ABBOUD, 2014, p. 64)

5.O Dossiê Copa do Mundo e Violações de Direitos Humanos em Curitiba integrou o Projeto Comitê Popular da Copa de Curitiba: garantia dos direitos humanos, articulação e construção coletiva do conhecimento, coordenado pelo Instituto Ambiens de Educação, Pesquisa e Planejamento. O dossiê traz uma análise crítica "dos resultados, mesmo que ainda não conclusivos, das ações desencadeadas 
com vistas à realização da Copa do Mundo FIFA 2014 em Curitiba" (INSTITUTO AMBIENS DE EDUCAÇÃO, PESQUISA E PLANEJAMENTO, s.d., p. 3). O Comitê Popular da Copa de Curitiba, por sua vez, é "um fórum amplo constituído por sujeitos e entidades da sociedade civil de diversos setores, tais como movimentos sociais, universidades, sindicatos, organizações não--governamentais, coletivos de mídia independente e comunidades atingidas", com o objetivo de denunciar e discutir eventuais violações de direitos decorrentes das intervenções urbanas relacionadas ao megaevento esportivo. O Comitê Popular atuava, à época, em diálogo com espaços similares instituídos nas 12 cidades-sede da Copa do Mundo de 2014. (INSTITUTO AMBIENS DE EDUCAÇÃO, PESQUISA E PLANEJAMENTO, s.d., p. 3).

6. O Relatório de Inspeção elaborado pela Comissão de Fiscalização do Tribunal de Contas do Estado do Paraná apontou um aumento de 660\% nos gastos dos empreendimentos para a copa, em relação aos valores apresentados nos contratos de financiamento firmados em 2010, chegando a $R \$ 125,8$ milhões. As despesas estaduais sofreram aumento de 620\% e chegaram a $\mathrm{R} \$ 56,3$ milhões (TRIBUNA DO PARANÁ, 2016).

7. Trincheiras são escavações que chegam a até oito metros de profundidade e solucionam conflitos viários por meio de um mergulho subterrâneo na via. Esse tipo de intervenção urbana causa menor impacto na paisagem da cidade e tem menor custo do que os viadutos. (SINDICATO DAS EMPRESAS DE TRANSPORTES DE PASSAGEIROS NO ESTADO DE PERNAMBUCO, s.d.)

8. A multa aplicada aos servidores revela mais um dos casos em que, segundo Streck (2005, p. 32) "vale a pena correr o risco": cada um deles foi condenado a pagar $\mathrm{R} \$ 3.958,00$, valor estipulado em maio de 2018. De acordo com Streck (2005, p. 32), os casos em que "vale a pena correr o risco" constituem o que ele denomina de "razão cínica brasileira", isto é, uma racionalidade produzida pelas classes dirigentes e pelo próprio establishment jurídico para impedir a percepção da realidade do país.

9. Conforme a rede de plataformas digitais AECweb/e-Construmarket, ponte estaiada é um tipo de ponte suspensa por cabos que partem de um ou mais mastros. Esse tipo de ponte é utilizada em casos nos quais se pretende reduzir a estrutura de suporte, mantendo-se livre um vão de grande dimensão embaixo do tabuleiro (AECWEB/E-CONSTRUMARKET, s.d.).

10. Em verdade, o incremento do turismo municipal não é mencionado como justificativa específica para a construção do Viaduto Estaiado, mas para todas as obras de mobilidade urbana realizadas no âmbito dos investimentos para a Copa do Mundo 2014. No documento eletrônico consultado por Madalena (2016, p. 223, nota 40), a menção ao turismo consta da seguinte passagem: “ 'Além de preparar a cidade para ao evento da Copa, essas obras trarão melhorias significativas para a 
mobilidade urbana e também para o turismo", destaca o presidente do Instituto de Pesquisa e Planejamento Urbano de Curitiba (Ippuc), Cléver de Almeida." (PREFEITURA MUNICIPAL DE CURITIBA, 2011). Ao que parece, a principal justificativa para a construção do viaduto foi a necessidade de deixar livre, abaixo dele, um vão de grandes dimensões. O próprio autor do projeto estrutural do Viaduto Estaiado, em apresentação de seu trabalho no Congresso Latino Americano de Construção Metálica, em 2014, afirmou que o desafio do projeto foi a "construção da infraestrutura, sem apoios intermediários, evitando assim a interrupção da passagem dos meios em circulação." (MIRANDA, 2014).

11. Os principais instrumentos de planejamento econômico previstos no artigo 165 da Constituição Federal são o Plano Plurianual (PPA), a Lei de Diretrizes Orçamentárias (LDO) e a Lei do Orçamento (LO). O PPA vincula a Administração Pública a diretrizes, objetivos e metas previamente estabelecidos tanto em relação às suas despesas como em relação aos programas de duração continuada. Além disso, ele conforma todos os demais planos e programas nacionais, regionais e setoriais adotados pelo Governo, conforme dispõe o artigo 165, §§ 1ㅇ e 4ㅇ da Constituição.

12. O plano diretor deve conter a estratégia para a intervenção imediata do Estado no espaço urbano e orientar, por meio da técnica do zoneamento, as ações para gestão da cidade. O Estatuto da Cidade (Lei 10.257/2001) traz, em seu artigo 42, todos os elementos obrigatórios do plano diretor e vincula o PPA, as diretrizes orçamentárias e o orçamento do município às diretrizes e prioridades nele contidas (artigo 41, § 1ํㅡ).

13.A gestão democrática é uma diretriz geral da política urbana, conforme previsto no Estatuto da Cidade (artigo 40, $\S 1^{\circ}$ ) e tem fundamento no artigo 1ํㅡ, parágrafo único, da Constituição, que prevê como regimes de governo da República brasileira a democracia representativa e a democracia direta, inclusive pela via participativa.

14.Rua (1998, p. 236) chama a atenção para o fato de que "os atores políticos são diversos e possuem características distintas": ao lado dos atores públicos (políticos cuja posição resulta de um mandato eletivo, a exemplo dos governadores, prefeitos e parlamentares; e burocratas), existem os atores privados (empresários, trabalhadores etc.); os tecnocratas (altos diretores de empresas públicas ou privadas, que transitam tanto na Administração Pública como no mercado privado); a mídia; e os movimentos sociais. Os atores particulares se organizam em grupos de pressão para encaminhar suas demandas e pressionar os atores públicos. Para uma análise completa dos diferentes atores políticos e da forma como atuam na produção da política pública, ver Rua (1998).

15. A afirmação está calcada no pressuposto de que o Poder Judiciário não atua como representante eleito pelo voto majoritário, mas de forma contramajoritária, inclusive para garantir os direitos das 
minorias no processo democrático. Por esse motivo, a solução dos conflitos na via judicial se dá por meio de uma decisão na qual o juiz interpreta e aplica a lei em um procedimento de justificação racional. Na via política, ao contrário, a solução dos conflitos decorre da capacidade dos atores de avançarem e recuarem estrategicamente na tentativa de fazer com que seus próprios interesses prevaleçam. Como consequência, o discurso jurídico é caracterizado pela racionalidade argumentativa, enquanto o discurso político é persuasivo (Conforme Rua, 1998).

16. Os bloqueios contra a efetividade da Constituição Econômica de 1988 podem ocorrer, segundo Clark, Corrêa e Nascimento (2017), por meio de três procedimentos: a) buscam inibir os processos de mudança da realidade econômica via supressão do texto constitucional; b) imobilizam os instrumentos de transformação social em razão da omissão de regulamentação constitucional; c) ou, a despeito de não alterar o texto constitucional, inviabilizam a sua efetivação em razão da implementação de uma economia política de austeridade.

17. A ponte estaiada é bastante empregada "no cruzamento de rios ou canais que necessitem de espaço para passagem de embarcações". Contudo, embora "em distâncias maiores que 150 metros" seja a melhor solução, por ser "a alternativa mais moderna, bonita e economicamente viável hoje", em vãos mais curtos o custo pode se tornar elevado, afirma o engenheiro Catão Francisco Ribeiro, diretor-executivo na Enescil Engenharia de Projetos. (AECWEB/E-CONSTRUMARKET, s.d.). De acordo com Miranda (2014), autor do projeto, o Viaduto Estaiado tem um vão central de 129 metros e dois vãos laterais de 70 e 26 metros.

18. Considerando-se que a escolha das cidades-sede da Copa do Mundo de 2014 se deu também por meio de eleição entre as cidades candidatas, os atos administrativos direcionados à realização dos eventos na cidade de Curitiba foram, da mesma forma que os atos administrativos adotados na esfera federal, vinculados por uma decisão política anterior: nesse caso, a decisão da Prefeitura de se candidatar ao posto de cidade-sede.

19. Conforme Comin (2017, p. 66-67), "uma parte da população curitibana, alguns especialistas e, principalmente, os moradores do entorno da obra, ainda hoje se indagam a respeito do real custobenefício de sua construção e das intenções do Poder Público em viabilizá-la. A opinião dos moradores sobre a construção não é unânime. Enquanto alguns enfatizam a valorização do bairro e dos imóveis e consideram como relevantes as melhorias no trânsito da região (GAZETA DO POVO, 2012), outros se perguntam se esta era realmente uma prioridade que justificou tamanho investimento público e ponderam sobre o aumento do volume de veículos na região (TRIBUNA PR, 2014)". 
Referências Bibliográficas:

ABBOUD, Georges. Discricionariedade Administrativa e Judicial: o ato administrativo e a decisão judicial. São Paulo: Editora Revista dos Tribunais, 2014.

BANDEIRA DE MELLO, Celso Antonio. Discricionariedade e Controle Jurisdicional. 2a edição. São Paulo, Editora Malheiros, 2012.

BRANDENBURG, Elena Justen. Grandes Projetos Urbanos: vetores de desigualdade socioespacial ? Análise prospectiva dos impactos e legados socioespaciais da Copa de 2014 em Curitiba. 2014. 293

f. Dissertação (Mestrado em Geografia) - Universidade Federal do Paraná, Curitiba, 2014.

Disponível em: < https://acervodigital.ufpr.br/bitstream/handle/1884/36352/R\%20-\%20D\%20\%20ELENA\%20JUSTEN\%20BRANDENBURG. pdf? sequence=1\&isAllowed $=\mathrm{y}>$. Acesso em $10 \mathrm{abr}$. 2019.

BRASIL. Tribunal de Contas do Estado do Paraná. Diretoria de Comunicação Social. Multados servidores do Ippuc por falhas em obra para a Copa 2014 em Curitiba. Curitiba, 14 jun. 2018. Disponível em: < https://www1.tce.pr.gov.br/noticias/multados-servidores-do-ippuc-por-falhasem-obra-para-a-copa-2014-em-curitiba/6072/N > Acesso em: dez. 2018.

BRASIL. Tribunal de Contas do Estado do Paraná. Relatório Final das obras de mobilidade urbana do projeto Copa 2014. Instrução da Presidência da Comissão de Fiscalização pela ciência do relatório a autoridades estaduais e municipais. Parecer do MPC pelo acolhimento do relatório com emissão de determinações, recomendações e encaminhamentos, pela instauração de procedimento de monitoramento e de tomada de contas extraordinária. Voto pela aprovação do relatório de inspeção com emissão de determinações, recomendações e encaminhamentos, pela instauração de procedimento de monitoramento e de tomada de contas extraordinária. Acórdão n.o 1934/16 Tribunal Pleno. [Curitiba], 5 de maio de 2016, Sessão n 15. Disponível em: < http://www1.tce.pr.gov.br/conteudo/acordao-1934-2016-do-tribunal-pleno/284459/area/10 >. Acesso em: 06 abr. 2019.

CLARK, Giovani; CORRÊA, Leonardo Alves; NASCIMENTO, Samuel Pontes do. A Constituição Econômica: entre a efetivação e os bloqueios institucionais. Revista da Faculdade de Direito da Universidade Federal de Minas Gerais, Belo Horizonte, n. 71, pp. 677 - 700, jul./dez. 2017 COMIN, Bianca Paola. A relação pessoa-ambiente no contexto urbano: uma análise perceptiva do Viaduto Estaiado Francisco H. dos Santos em Curitiba-PR. 2017. 190 f. Dissertação (Mestrado em Meio Ambiente e Desenvolvimento) - Universidade Federal do Paraná, Curitiba, 2017. Disponível 
em: < https://acervodigital.ufpr.br/bitstream/handle/1884/53430/R\%20-\%20D\%20\%20BIANCA\%20PAOLA\%20COMIN\%20. pdf? sequence=1\&isAllowed=y >. Acesso em: 10 abr. 2019.

COSTA, Gustavo Vidigal; CLARK, Giovani. Desplanejamento Estatal: o exemplo da Copa do Mundo de 2014 no Brasil. In: XXI Encontro Nacional do CONPEDI, 2012, Universidade Federal de Uberlândia - UFU. Anais do XXI Encontro Nacional do CONPEDI. Florianópolis: Fundação BoiteuX, 2012, p. $3785-3808$.

CURITIBA. Prefeitura Municipal. Agência de Notícias. Empresa francesa apresenta projeto de VLP elétrico para mobilidade em Curitiba. Curitiba, 08 jun. 2016. Disponível em:< http://www.curitiba.pr.gov.br/noticias/empresa-francesa-apresenta-projeto-de-vlp-eletrico-paramobilidade-em-curitiba/39908 > Acesso em: 09 abr. 2019.

CURITIBA. Prefeitura Municipal. Agência de Notícias. Publicados editais de licitação para quatro obras da Copa. Curitiba, 22 dez. 2011. Disponível em: <

http://www.curitiba.pr.gov.br/noticias/publicados-editais-de-licitacao-para-quatro-obras-dacopa/25429 >. Acesso em: 08 abr. 2019.

CURITIBA. Secretaria Municipal de Obras Públicas. Edital de Concorrência no CN/081/2011SMOP/OPP. Curitiba, 22 dez. 2011. Disponível em < http://multimidia.curitiba.pr.gov.br/2013/00135929.pdf >. Acesso em: 08 abr. 2019.

CURITIBA. Lei 13.378, de 11 de dezembro de 2009 e anexos. Dispõe sobre o plano plurianual para o período 2010/2013. Disponível em: < https://leismunicipais.com.br/a/pr/c/curitiba/leiordinaria/2009/1337/13378/lei-ordinaria-n-13378-2009-dispoe-sobre-o-plano-plurianual-para-operiodo-20102013 >. Acesso em: 11 abr. 2019.

ENTERRÍA, Eduardo García de. La lucha contra las inmunidades del poder em el derecho administrativo (poderes discrecionales, poderes de gobierno, poderes normativos). Revista de administración pública, n. 38, 1962, págs. 159-208. Disponível em: < https://dialnet.unirioja.es/servlet/articulo?codigo=2112627 >. Acesso em: 08 jan. 2019.

FARIA, Edimur Ferreira de. Controle do Mérito do Ato Administrativo pelo Judiciário. 2a edição. Belo Horizonte, Editora Fórum, 2016.

GASTOS com a Copa em Curitiba superaram em mais de 600\% os valores previstos. Tribuna do Paraná (on-line), Curitiba, 10 mai. 2016. Caderno de Mobilidade Urbana. Disponível em: < https://www.tribunapr.com.br/noticias/parana/gastos-com-a-copa-em-curitiba-superaram-emmais-de-600-os-valores-previstos/ >. Acesso em: 10 abr. 2019. 
HARVEY, David. Rebel Cities: from the right to the city to the urban revolution. London, New York: Vision, 2012.

The Political Economy of Public Space. In: LOW, Setha; SMITH, Neil (Ed.). The Politics of

Public Space. New York: Routledge, New York, 2006, p. 17-34.

INSTITUTO AMBIENS DE EDUCAÇÃO, PESQUISA E PLANEJAMENTO. Copa do Mundo e Violações de Direitos Humanos em Curitiba. Curitiba: Comitê Popular da Copa de Curitiba, s.d.. Disponível em: : http://www.direitoamoradia.fau.usp.br/wp-content/uploads/2013/11/COPA-DO-MUNDO-EVIOLA\%C3\%87\%C3\%95ES-DE-DIREITOS-HUMANOS-EM-CURITIBA.pdf >. Acesso em: 08 abr. 2019. JUSTI, Adriana. Viaduto da Copa em Curitiba que custou R\$17 mi a mais é liberado. Paraná RPC (on-line), Curitiba, 09 abr. 2014. Disponível em: <

http://g1.globo.com/pr/parana/noticia/2014/04/viaduto-da-copa-em-curitiba-que-custou-r-17-mimais-e-liberado.html >. Acesso em: 08 abr. 2019.

KELSEN, Hans. Teoria Pura do Direito. Tradução: João Baptista Machado. 2a ed. São Paulo: Martins Fontes, 1987.

MADALENA, Luis Henrique. Discricionariedade Administrativa e Hermenêutica. Salvador: Editora Juspodium, 2016.

MARCHIORI, Rapahel. O alto preço do viaduto estaiado. Gazeta do Povo (on-line), Curitiba, 25 abr. 2012. Caderno de Urbanismo. Disponível em: < https://www.gazetadopovo.com.br/vida-ecidadania/o-alto-preco-do-viaduto-estaiado-21luss1srh0n89bs1pj2yywjy/ >. Acesso em: 08 abr. 2019.

MIRANDA, Mário de. Um Viaduto Estaiado em Curitiba. Contribuição Técnica. VI Congresso LatinoAmericano da Construção Metálica. 2014. São Paulo. Disponível em <

https://www.abcem.org.br/construmetal/2014/downloads/contribuicao-tecnocientifica/Mario-deMiranda.pdf >. Acesso: 08 abr. 2019.

MORAES, Germana de Oliveira. Controle Jurisdicional da Administração Pública. 2a edição. São Paulo, Editora Dialética, 2004.

OBRA de travessia transforma o conceito de mobilidade urbana em Cuiabá. In: Sindicato das Empresas de Transportes de Passageiros no Estado de Pernambuco (Blog). S.d. Disponível em: < Fonte: http://urbana-pe.com.br/obra-de-travessia-transforma-o-conceito-de-mobilidade-urbanaem-cuiaba >. Acesso em 08 abr. 2019.

PONTE estaiada é indicada para vencer grandes vãos: AECweb/e-Construmarket. Rede de plataformas digitais, portais de conteúdo e conexão de profissionais da área da construção e 
operação, s.d.. Disponível em: < https://www.aecweb.com.br/cont/m/rev/ponte-estaiada-eindicada-para-vencer-grandes-vaos $11725 \quad 0 \quad 1$ > Acesso em: 08 abr. 2019.

RUA, Maria das Graças. Análise de Política Públicas: Conceitos Básicos. In: Maria das Graças Rua; Maria Carvalho. (Org.). O Estudo da Política: Tópicos Selecionados. Brasília: Paralelo 15, 1998. SANTOS, Oliveira. Direito Administrativo e Sciencia da Administração. Rio de Janeiro: Jacintho Ribeiro dos Santos, 1919.

STRECK, Lenio. Hermenêutica Jurídica e $(m)$ Crise: uma exploração hermenêutica da construção do Direito. Porto Alegre: Livraria do Advogado Editora, 2005.

. Que maldição estaria por trás da interpretação do direito em Kelsen ? Revista Consultor Jurídico (on-line). Publicado em 13 nov. 2014. Disponível em: < https://www.conjur.com.br/2014nov-13/senso-incomum-maldicao-estaria-interpretacao-direito-kelsen > Acesso em: 08 abr. 2019. TASSO, Edson Navarro. Superfaturamento, Direcionamento e Desperdício de Dinheiro Público na Licitação do Viaduto Estaiado de Curitiba. In: BLOG DO NAVARRO (Blog). 04 abr. 2012. Disponível em: < http://blogdonavarro2010.blogspot.com/2012/04/construcao-de-viaduto-estaiado-na.html >. Acesso em 09 abr. 2019.

Trabalho enviado em 29 de abril de 2019

Aceito em 02 de fevereiro de 2020 